\title{
TAX-EXEMPT INTEREST OF LIFE INSURANCE COMPANIES A STUDY IN "DISCRIMINATORY" TAXATION
}

\author{
HAROLD WURZEL $\uparrow$
}

The business of insurance has proven over the years an extremely difficult subject for Federal taxation. The determination of what should constitute "income" in the case of insurance companies, combined with differences in the methods of doing business of mutual and stock companies, has presented the Congress with problems of unusual complexity. ${ }^{1}$

THE occasion for this statement must have been a rare feast interrupting the Tax Court's drab routine. It all started with a disintegrating casualty company's last gasp, challenging the constitutional authority of Congress to saddle mutual casualty insurance companies (under the 1942 Revenue Act) with a tax on the gross amount of their investment income and (net) premiums, reduced only by policyholders' dividends and wholly tax-exempt interest. Maybe the learned Judges of the Tax Court were carried away by nostalgic memories of their law school days-in any event, the controversy over a moderate $\$ 12,500$ deficiency wound up in a free-for-all displaying at least as much youthful gusto as recondite erudition. The decision, handed down only a few days before enactment of the Life Insurance Company Income Tax Act of 1959,2 regales the legal historian with cases decided in the year of George Washington's Farewell Address, and the first opinion in Pollock v. Farmers' Loan \& Trust $\mathrm{Co}^{3}$ is one of the more modern authorities invoked. In the light of these very recent developments, the yesteryear casebooks on tax law, abounding with musty controversies of constitutional law, may yet prove to be the most progressive.

If the small case of a moribund casualty company could arouse a busy Tax Court to the production of a 52-page booklet, there is no predicting the dimensions of cases already in prospect under the 1959 Act, involving a significant number of major life insurance companies. The problem which may cause the legal pundits once again to dust off their 18th-century tomes is briefly this: Under the 1959 Act, are Life Insurance Companies being taxed on their tax-exempt interest?

If a price tag may be attached to the controversy over the method of taxing insurance company investment income, it is, according to Treasury estimates,

$\dagger$ Member of the New York bar; Editor, Research Institute of America, Inc.

1. Penn Mut. Indem. Company, 32 T.C. 653, 654 (1959) (Raum, J.).

2. 73 Stat. 112 (1959), 26 U.S.C.A. $\$ \$ 801-20$ (Supp. 1960), amending INT. REv. CODE of $1954 \$ \S 801-13$ [hereinafter referred to in discussion as the 1959 Act]. Proposed Regulations under $\$ \$ 801-06$ of the Act have been issued. 25 Fed. Reg. 7983 (Aug. 18, 1960).
3. 157 U.S. 429 (1895). 
in the neighborhood of $\$ 35$ million in tax money. ${ }^{4}$ This estimate, however, is only a fraction of the total sum involved. First, it is but an annual figure and must, therefore, be multiplied by the number of years during which the problem remains unsolved. Second, it disregards the fact that the 1959 Act itself, which increases the tax burden for the companies in general, has commensurately enhanced the attractiveness of securities paying tax-free interest ; thus, the present investment in tax exempts may not accurately represent the size of future investments. The investment managers of leading life insurance companies are well aware of this development, even if not all tax-exempt bonds are, on a net-yield basis, in a position to compete with some high-ranking securities of the taxable kind now available. Paradoxically enough, the Treasury may in the end lose more by winning than by losing the battle, and quite contrary to the companies' dire predictions, ${ }^{6}$ the fruits of a Treasury victory are apt to be reaped by the market in tax-exempt securities.

\section{Two ImMunitres of Stature}

There is nothing in the 1959 Act specifically excluding life insurance companies from the privilege of reducing their tax burden through the ownership of state or municipal bonds. If a question does arise whether they are being deprived of a substantial part of that benefit, it arises only indirectly, "by operation of law," as it were-a law conceived and drafted with care and skill, but in some of its innovations yet in need of an old-fashioned baptism of fire. More precisely, it arises through the interplay of two tax immunities of totally different purposes, though both of high rank and equally impressive tradition:

(1) The exemption from federal income tax of interest on state and municipal securities, and

(2) the exemption of that portion of a life insurance company's investment income that state law compels it to set aside each year as a contribution to the reserve for its policyholders.

For purposes of a succinct identification we shall call the former the interest exemption, the other the reserve deduction, but bearing in mind that both terms are concessions to brevity and not intended to prejudge the technical nature of the benefit as an exemption, exclusion, credit, or deduction.

4. Hearings on H.R. 4245 Before the Senate Finance Committee, 86th Cong., 1st Sess. 51 (1959) [hereinafter cited as Hearings]. As much as $\$ 100$ million is estimated to be at stake, if the companies' revolt engulfs partially exempt interest and intercorporate dividends. Ibid.

At the end of 1958, the tax exempt bonds which life insurance companies owned (about $\$ 3.7$ billion) amounted to $2.5 \%$ of their aggregate assets. This represented a three-fold increase in amount over ten years. Institute of Life Insurance, LIFE Insurance FAct Book 1959, 69. Moreover, some companies now admit to eight times the average figure of $2.5 \%$ and more. Hearings at 304 .

5. See statement by Mr. Clarence J. Myers, chairman and president of the New York Life Insurance Co., reported in Wall Street Journal, January 11, 1960, p. 8, col. 1.

6. Hearings at 307. 


\section{Interest Exemption}

As a matter of protocol, the interest exemption takes precedence. Its seniority is due not only to greater age, but also to its apparently impregnable position within the federal income tax structure. It is a cornerstone set in place even in advance of the sixteenth amendment-a solemn assurance given as far back as 1910 by prominent senators to a group of apprehensive governors (among them the later Chief Justice Hughes). ${ }^{7}$ It has survived all agitation for its abolition, a presidential request for its repeal (1938), ${ }^{8}$ the demise of the closely related immunity of state-paid salaries, promptly exploited by Congress (1938-1939) ${ }^{9}$ a death warrant endorsed by a Senate Finance Committee in quest of wartime revenues (1942), ${ }^{10}$ and an almost unanimously unfavorable, perennially reaffirmed verdict of tax experts. In the face of an extraordinary growth in the interest exemption's financial significance, as a result of both ever-increasing tax rates and a state-local indebtedness now in the neighborhood of $\$ 60$ billion, ${ }^{11}$ this is, by all standards, a combat record of rare distinction.

The site of the interest exemption in the 1954 Internal Revenue Code is section 103 (a), which reads in part as follows :

(a) General rule. Gross income does not include interest on-

(1) the obligations of a State, a Territory, or a possession of the United States, or any political subdivision of any of the foregoing, or of the District of Columbia;

(2)

In the form just quoted, however, this provision has not been applied to life insurance companies. They must include their tax-exempt interest in their gross income, ${ }^{12}$ and may thereafter remove the item from taxation by availing themselves of whatever compensating deduction or other device the applicable revenue laws may grant them. But this method of in-and-out is not designed to affect the exemption as a matter of principle or substance. It is closely related to the nature of the life insurance business, to the fact that the companies' entire investment income, taxable and otherwise, plays

7. See Brazer, Interest on State and Local Bonds and the Federal Income Tax, in 1 Tax Reviston Compendium Submitred to House Commitree on Ways and Means 721 (1959) [hereinafter cited as TAX Revision Compendium]; Knollenberg, Book Review of Taxation of Government Bondholders and Employees: The Immontty Rule and the Stxteentr Amendment, 49 Yale L.J. 156 (1939).

8. President Roosevelt's message to Congress, April 25, 1938, quoted in 1 Mertens, Law of Federal Incone Taxation $\$ 8.01$ n.2 (1956) [hereinafter cited as Mertens].

9. Graves v. New York ex rel. O'Keefe, 306 U.S. 466 (1939), overruling Collector v. Day, 78 U.S. (11 Wall) 113 (1870) ; Helvering v. Gerhardt, 304 U.S. 405, rehearing denied, 305 U.S. 669 (1938). For congressional action exploiting these cases, see Public Salary Tax Act of 1939, ch. 59, 53 Stat. 574, amending Int. Rev. Code of 1939, § 22(a).

10. SeN. Rep. No. 1631, 77th Cong., 2d Sess. 75 (1942). Taxation was proposed for future issues only. It was stricken from the bill after debate on the floor and before the bill was sent to conference. See 1 Mertens $\$ 8.17$, at 25-26.

11. Hearings at 649.

12. Midland Nat'l Life Ins. Co., 14 B.T.A. 200 (1928). 
its part in feeding the reserves for policyholders, in establishing the companies' solvency to the satisfaction of the State Insurance Commissioner, and in substantiating the recognition taxwise (through deduction, credit, or exclusion) of their commitment to the policyholders. As under prior revenue acts and under the 1939 Code, ${ }^{13}$ the technical form of asserting what to others is the exclusion under section $103(\mathrm{a})$ is a deduction. ${ }^{14}$

\section{The Reserve Deduction}

1. The Reserve. An inherently hazardous business and a proverbially conservative management add up to the word reserve. The variety of the reserves' contemplated purposes is infinite. Epidemics, errors of calculation, investment losses, economic depression with resulting policyholders' demands for cash (policy loan or surrender value), and many other unpredictable factors want to be recognized and provided against, some under pressure of state regulation, some as a matter of option and prudence. The present discussion, however, will be limited to a single and unique species of reserve, the "life insurance reserve":

The simplest way in which to define the reserve is to say that it is that fund, which together with future premiums and interest, will be sufficient to pay future claims. ${ }^{15}$

The fundamental role of this reserve is particularly conspicuous in levelpremium life insurance. If the premium were to change every year as the insured advances in age, life insurance would fail of its purpose. Its cost would rise to a prohibitive level at the time when it is most needed. For this eminently practical reason the periodic premium is computed so as to remain constant throughout the life of the policy-which entails a purposeful "overcharge" in the early years of the policy and an equalizing "undercharge" in later years. ${ }^{16}$ The fund which accumulates due to the premium overcharge is available for investment. The "reserve" will therefore be fed by the premium overcharge plus the yield which the investment of the overcharge produces year after year. The premium rates which the company deems necessary to meet future policy liabilities will depend on the interest which it assumes its invested reserve fund will earn. ${ }^{\mathbf{1 7}}$

The company's choice of a suitable "assumed interest rate," is quite limited, however. The lower the rate, the higher the premium; the higher the rate, the lower the premium. Hence, competition, with its pressure for lower

13. Int. Rev. Code of $1939, \S 201$ (c), added by ch. 619,56 Stat. 868 (1942).

14. INT. Rev. CoDE of 1954, $\$ 809$ (d) (8) (A) (i), as amended, 73 Stat. 121 (1959).

15. Huebner \& Black, Life Insurance 191 (5th ed. 1958).

16. See $i d$. at 6 .

17. See Judge Littleton's explanation of the role of the earnings factor, Massachusetts Mut. Life Ins. Co. v. United States, 74 Ct. Cl. 162, 166, 56 F.2d 897, 899 (1932). The term "interest" should be understood exclusively as an element of calculation-it does not connoțe "interest" in any legal sense. 
premium rates, will prevent a company from selecting an assumed interest rate which is inordinately lower than its actual investment earnings rate. Conversely, the State Insurance Commissioner, the guardian of the companies' solvency, will furnish the ceiling. He will not tolerate an assumed interest rate of 8 per cent if the company can barely expect to earn 4 per cent. In practice, the companies have been more conservative than the Commissioners ${ }^{18}$ -which, it is to be remembered, spells higher premiums, a speedier build-up of the reserve through those higher premiums, with less help from investment earnings, and in pleasant addition, a wider margin of profits consisting of the excess of actual over assumed earnings on investments.

2. The Deduction. Setting aside funds now, in order to provide against liabilities to be discharged at an unknown time in the future has seldom appealed to Congress in its capacity as the purveyor of federal revenues. Principles, however, are pliable enough to yield to practicalities, if the practicalities, as in the case of the life insurance reserve, are sufficiently persuasive.

In the halcyon days of little or no taxation, companies had contracted to insure policyholders for an immutable premium, calculated on the basis of an assumed interest yield from investments. If the investment yield allocated to build up reserves had been taxed, and thereby reduced, the companies would have been compelled to meet this deficiency by dipping into their own funds, creating a risk of insolvency for those companies with limited free resources. Moreover, taxation of the interest component would have necessitated higher premium rates for future policies, subject to fluctuation with each change in the tax rate. ${ }^{19}$ High premiums, and particularly premiums changing with the tax-rate schedule, would tend to deter the public from buying insurance, at least from United States companies, and once the decline of policy purchases sets in, the very essence of life insurance, the law of average based on the participation of the largest possible number, would be in jeopardy. ${ }^{20}$

18. The Commissioners usually accept a rate of $31 / 2 \%$ when checking on a company's solvency; stock companies generally use an assumed rate of $3 \%$ and mutuals $21 / 2 \%$ or less (with equalization through "dividends"). HUEBNER \& BLACK, op. cit. supra note 15, at 192. The required change in mortality table assumptions caused by the new $1958 \mathrm{CSO}$ table "may lead some companies to a re-examination of interest rate assumptions." Sternhell, The Commissioners 1958 Standard Ordinary Mortality Table, 14 C.L.U. JournaI 255, 269 (1960).

19. In addition, the bookkeeping problems necessitated by the creation of separate reserve funds, one of which has a taxable interest component and the other of which does not, stagger the imagination.

20. This does not imply that the annual increment to the reserve from investment income must forever remain unmolested by the tax collector on a current basis. Proposals to the contrary have again been submitted. See, e.g., Lent, The Tax Treatment of Life Insurance, 3 Tax Revision Compendium 1995, 2011. But the removal of the present tax shelter would have to affect the policyholder more directly than through interference with the formation of the policy reserve or with the computation or long-term consistency of the premium. 
For these reasons, Congress adopted a hands-off policy, manifested by a reserve deduction. While computation of the deduction has varied over the decades, its purpose has always been to immunize from tax that portion of the companies' investment income that was properly allocable to the policyholders' reserve.

From 1921 to 1941 Congress itself fixed 4 per cent ${ }^{21}$ of the reserve fund required by state law as the amount of investment income which would ordinarily be immune from tax. ${ }^{22}$ The 4 per cent deduction reduced the companies' contribution to the Treasury to a minimum, particularly as their actual investment income dropped to a level of about $3 \mathrm{I} / 4$ per cent. Under wartime conditions this was no creditable performance. Consequently, in 1942 a new system was introduced, this time adapting the reserve deduction to the average experience of the entire industry and expressing it, not in terms of a percentage of the reserve funds, but rather as a percentage of (taxable) net income. It was the main ingredient of the "reserve and other policy liability credit," defined as an amount computed by multiplying the (normal-tax and surtax) net income by a figure to be determined and proclaimed by the Secretary of the Treasury, according to a statutory formula, for each taxable year. ${ }^{23}$

The formula, during its first few years, worked to almost everybody's satisfaction. From 1942 to 1946 it produced a percentage figure ranging from 91.98 to 95.95 , leaving only from 8.02 to 4.05 per cent of the (taxable) net investment income to be taxed. Then the computer started sputtering and

21. After 1932, the rate was reduced to $33 / 4 \%$ if the company's "assumed" interest rate dropped below 4\%. See Revenue Act of 1932, ch. 209, § 203(a) (2), 47 Stat. 223-25. See 8 Mertens $\$ \S 44.25$ n.24, 44.28 n.74 (1942 ed.).

22. During this period, the provisions regarding taxation of life insurance companies were: Revenue Act of 1921, ch. 136, $\$ \$ 242-45$, 42 Stat. 261-62; Revenue Act of 1924, ch. 234 , $\S ~ 242-45$, 43 Stat. 288-90; Revenue Act of 1926, ch. 27 , $\$ \S 242-45$, 44 Stat. 47-48; Revenue Act of 1928, ch. 852, $\$ \S 201-03$, 45 Stat. 842-44; Revenue Act of 1932, ch. 209, $\S \S 201-03,47$ Stat. 223-25; Revenue Act of 1934, ch. 227, $\$ \$ 201-03$, 48 Stat. 73133; Revenue Act of 1936, ch. 690, $\S \S 201-03$, 49 Stat. 1648-1756; Revenue Act of 1938, ch. $289, \$ \S 201-03,52$ Stat. 522-24; Int. Rev. Code of 1939, $\$ \S 201-03$.

There was a reserve deduction also under earlier legislation, but its purpose was essentially different. It was aimed at eliminating "unearned" premiums at a time when premiums collected were among the main items of gross income and the tax base was not restricted, as it was under the 1921 and subsequent acts, to investment income. 8 MERTENS $\S \S 44.27,-.28$. It should be noted that the 1959 Act, in a measure, reverts to the pre-1921 method by allowing underwriting gains and losses to affect the tax result. INT. REv. ConE of 1954, §§ 809-12, as amended, 73 Stat. 121-27 (1959) (so-called phase two of the tax computation). Yet it retains what characterized the tax treatment since 1921, investment income as a separate component of the tax base.

23. Int. Rev. Code of $1939, \S 202$ (b), as amended, ch. 619,56 Stat. 870 (1942). In its essence, the statutory formula reflected the ratio of a modified reserve deduction (means of the reserves times a specified reserve earnings rate) to net income before deduction of tax-exempt interest, all on a nationwide basis. The resulting percentage figure was then applied by the taxpayer to its individual (taxable) net income (that is, after deduction of tax-exempt interest), and so applied was the credit allowed to escape taxation. 
came up with embarrassing figures: 100.66 per cent for 1947 and 102.43 per cent for $1948 .{ }^{24}$ A change of formula was indicated and accomplished by the Revenue Act of 1950 . The new formula resulted in a more readily justifiable 93.55 per cent for $1949^{26}$ and 90.63 per cent for $1950,{ }^{26}$ but still a somewhat ample shelter. In 1951 the reserve deduction dropped to the equivalent of about 87 per cent when, in lieu of the "reserve and other policy liability credit," a flat tax rate of $33 / 4$ per cent was applied to the first $\$ 200,000$ and $6 \% / 2$ per cent to any excess of (adjusted) normal-tax net income. ${ }^{2 \pi}$ For post1954 years the 1954 Code reverted to the 1942 formula (revised edition). ${ }^{28}$ Yet when the discredited computer attempted to rehabilitate itself by suggesting $\$ 2.38$ per cent as appropriate for $1955,,^{29}$ it was, once again, the "wrong" figure, though this time the error was in the opposite direction. A tidal wave of legislation corrected the indiscretion. ${ }^{30}$ It reinstated for 19551957 the prior system of applying the same tax rates as apply to ordinary corporations and taking into account the required additions to reserve by way of a reserve deduction. The deduction rate was $87 \mathrm{I} / 2$ per cent of net investment income (except the portion allocable to nonlife reserves) on the first $\$ 1$ million and 85 per cent beyond that limit. ${ }^{31} \mathrm{~A}$ sulky computer went into seclusion for 1956, ineffectively soliloquizing that for 1957 the proper figure would have been 77.66 per cent. ${ }^{32}$

3. The 1959 Act. Congress, understandably impatient with the makeshift and stopgap legislation of recent years, adopted a new approach to the reserve deduction in drafting the 1959 Act. It rejected a formula system based on a nationwide average, which penalizes or rewards individual companies depending on their deviation from the norm. It found equally unacceptable the

24. For the yearly percentages, see T.D. 5188, 1942-2 Cum. Bull. 151; T.D. 5328, 1944 Cunr. Bull. 333; T.D. 5427, 1945 Cum. Bull. 243; T.D. 5486, 1946-1 Cum. Bull. 127; T.D. 5547, 1946-2 Cuss. Bull. 92; T.D. 5595, 1947-2 Cun. Bull. 96; T.D. 5689, 1949-1 CuM. BuLr. 119.

25. T.D. 5813, 1950-2 CuM. BuLc. 65. The change substituted the average rate of interest assumed by the companies for the previous "reserve earnings rate," which had been inflated by a generous admixture $(65 \%)$ of a $3 \frac{1}{4}$ percentage as assumed interest.

26. T.D. 5831, 1951-1 CuMr. Bulz. 56.

27. Int. Rev. Code of 1939, $\S \S 201$ (a) (1), 203(A), as amended, ch. 521,65 Stat. 507 (1951), ch. 592, 66 Stat. 444 (1952), ch. 512, 67 Stat. 616 (1953) ; INT. Rev. Code of 1954, $\S 802(\mathrm{~b})$. Adjusted normal-tax net income meant essentially (taxable) net investment income, with some adjustments not material in the present connection.

28. INT. Rev. Cone of 1954, § 802 (a). See for the intention of continuity, S. Rep. No. 1622, 83d Cong., 2d Sess. 409 (1954).

29. T.D. $6146,1955-2$ CuMr. BuLc. 280.

30. Life Insurance Co. Tax Act for 1955, ch. 83, 70 Stat. 36 (1956), amending INT. REv. CoDE of 1954, \& 802(a), extended by ch. 696, 70 Stat. 633 (1956), and P.L. 85-345, 72 Stat. 36 (1958). This legislation expanded the tax base (investment income) to cover royalties, not only rents, income from entering into, altering, or terminating lease or mortgage agreements, income derived from a business other than insurance.

31. INT. REv. CoDE of 1954, § 804(a), as amended, ch. 83, 70 Stat. 36 (1956).

32. T.D. 6250, 1957-2 CuMr. BuLr. 366. 
use of the individual company's assumed interest rate, which could be adjusted to suit its tax convenience. Instead, it adopted a new approach. ${ }^{33}$ The applicable interest rate is now the average interest earned (not assumed) by the individual company in the current and four prior taxable years on its investment assets, but in no event is the rate to exceed the current earnings rate. ${ }^{34}$ Congress so decided on the somewhat optimistic theory "that the competitive pressures within the industry will in the long run force various companies to build into their price structure for their policies a credit for interest on something like this basis."35 Multiplied by presently existing reserves, however, the applicable average or current interest rate would tend to give a deduction substantially larger than the amount which companies actually credit to the policy reserve, for the annual addition to reserves is calculated by multiplying the reserve by an "assumed" interest rate which is appreciably lower than the rate earned by the company. The disparity between the actual credit and the allowed deduction is aggravated by the speedy and insurancewise wholesome buildup of reserves which a low assumed interest rate produces. To adjust for this "temporary" disparity, the act adopts a "rule of thumb" which for tax purposes reduces the reserve by ten per cent for every one per cent by which the applicable earnings rate exceeds the "assumed" rate. ${ }^{36}$

The reserves so adjusted, when multiplied by the applicable earnings rate, represent the "policy and other contract liability requirements." These policy requirements are then divided by net investment income (including taxexempt interest), called the "investment yield," and this step produces the percentage of every item of investment yield that is excluded from the com-

33. The 1959 Act introduces a three-phase procedure for the taxation of life insurance companies.

The present discussion is limited to the interrelation of interest exemption and reserve deduction (exclusion), a problem fraught with both real and false issues of constitutional law. This limitation, imposed by the exigencies of legal analysis, eliminates (but is not intended to belittle) such financially equally important items as partially exempt interest and intercorporate dividends, not to mention such collateral questions as the nature of a market discount on a life insurance company's purchase of municipals. See Treas. Release TIR-230, May 18, 1960; Rev. Rul. 60-210, 1960 INT. Rev. Bull. No. 22, at 10. What is more, it permits the treatment to concentrate on investment income (phase one), which raises the problem of interrelation directly and squarely, and thereby to leave undecided the controversial question whether the same problem is also inherent in phases two (gain and loss from operations) and three (distributions to shareholders of stock companies). For the latter question, see the summary of an address by Mr. Devereaux F. McClatchey, general counsel of the National Association of Life Companies, to the NALC 1960 Convention, in The National Underwriter, July 30, 1960, p. 11. The address deals with "Tax Exempt Interest and Intercorporate Dividends under the 1959 Life Insurance Company Income Tax."

34. INr. Rev. CoDE of 1954, $\S 805$, as amended, 73 Stat. 118 (1959).

35. S. Rep. No. 291, 86th Cong., 1st Sess. 5 (1959).

36. See id. at 16. For a criticism of the "rule of thumb," see Roy E. Moor, Tax Treatment of Insurance Companies, 3 TAX Revision Compendium 1983, 1993. 
pany's income. ${ }^{37}$ This exclusion is the present-day substitute for the former reserve deduction.

\section{Changing Patterns of Coexistence}

The 1959 Act preserves, in their substance, both immunities, the interest exemption and the reserve deduction, and its prenatal history shows that this continuity is intended and deliberate. ${ }^{38}$ Each of the two inmunities has its very own raison d'être. They have in common an unusual vitality, a wellestablished tradition. Their purposes, however, are so disparate and incomparable, their functions so unrelated to each other, that when the twain meet in the hands of the same taxpayer, neither adds to, or detracts from, the "equity" of the other.

It is appropriate to bear this point in mind, because "equities" have an uncontrollable way of intruding upon our judgment when tax benefits, however meritorious and unquestionable if taken separately, are bunched into a cumulative benefit which offends our sense of balance. 39 But the "visceral" approach to the bunching is no reliable tool in determining when the cumulative effect of multiple tax benefits constitutes the kind of "duplication" to which an objection may properly be taken. Cumulative effect of tax benefits is not inherently, or by force of logic, duplication of tax benefits. "Duplication" presupposes a double benefit granted to the same item. Whether or not there is such an identity is primarily a matter of policy and statutory law. Thus, by

37. INT. Rev. Code of 1954, § 804(a) (1), as amended, 73 Stat. 115 (1959).

38. It is, therefore, unnecessary to inquire whether Congress's motive was belief in the intrinsic merits of both immunities, an assumption that the Constitution so required, or simply political expediency. It is regrettable, however, that as terminology-conscious a group as the legal profession has been content to characterize deductions approved by Congress in the exercise of its legislative functions as matters of "grace." There is an endless variety of conceivable motives for a member of Congress to approve of or consent to a deduction-from a lofty dictate of conscience, sense of duty, economic wisdom, down to the realistic exigencies of party politics. In any event, the exercise of a mystical power to dispense "grace" is probably about the last thing of which he would care to be accused.

39. The Supreme Court itself occasionally succumbs to this human fraility. In United States v. Benedict, 338 U.S. 692 (1950), reversing 112 Ct. Cl. 550, 81 F. Supp. 717 (1949), it referred (by way of an illustration close to the facts of the case) to a trust which realized a long-term capital gain of $\$ 60,000$ and made a charitable contribution of $\$ 30,000$. Since the charitable deduction from gross income was allowed for any amount of gross income contributed to charity $(\$ 30,000)$ and, in computing net income only $50 \%$ of the long-term capital gain was to be taken into account $(\$ 30,000)$, the cumulative effect of these two entirely unrelated benefits would be a net income of zero, according to accepted canons of statutory interpretation. This was to much, or rather too little, for the Supreme Court to accept. It proceeded to give "gross income" a meaning which reduced it to the amount to be taken into account in computing net income, so that $\$ 15,000$ remained as a tax base.

The result found its way into the Code of 1954, InT. REv. CodE of 1954, $\$ 642$ (c). H.R. 9662, 86th Cong., $2 d$ Sess., now awaiting its revival, would yield to an even less liberal treatment. 
giving the taxpayer an optional standard deduction, the law may define the various items which it intends to take into account, and taking a separate deduction for any such item, in addition to the standard deduction, will, by definition only, create a duplication, a double benefit for the same item. Similarly, the law may define what it means by the reserve deduction, and if by that definition it would deduct from taxable income an amount which it has never charged to the taxpayer in the first place, it may call for an adjustment to eliminate the unintended duplication, a double benefit for the identical item. In both cases, however, the legislator must make sure that he is acting within his powers. Even though he regards benefits as duplicating each other, because making a double allowance for the same item, he may not remove the duplication by removing a benefit which is beyond his jurisdiction. $\mathrm{He}$ is (arbitrariness aside) not accountable to anybody in deciding what constitutes a duplication, but he is accountable for the choice of his remedies to eliminate the duplication. In this respect he has not always succeeded in remaining entirely above reproach.

On the premise that, in one form or another, the two benefits, interest exemption and reserve deduction, must be joined, there is but a limited number of combinations and permutations available, even when treating them as equals rather than weighing them on the scales of either their political or economic importance. Prior to the 1959 Act three combinations have emerged, each of which has governed a substantial number of years within the last four decades. They may be illustrated by a simple set of facts.

Assume a net investment income of $\$ 100$-after deductible investment expenses, but before eliminating tax-exempt interest. Wholly tax-exempt interest amounts to $\$ 20$, and the reserve deduction from investment income to $\$ 70$. What is the company's taxable income?

\begin{tabular}{|c|c|c|c|}
\hline & Pattern $A$ & Pattern B & Pattern $C$ \\
\hline & $\$ 100$ & $\$ 100$ & $\$ 100$ \\
\hline \multirow[t]{2}{*}{ less } & 20 & 20 & 20 \\
\hline & $\$ 80$ & $\$ 80$ & $\$ 80$ \\
\hline less & $50(=70-20)$ & 70 & $56[=70-(20 / 100 \times 70)]$ \\
\hline $\begin{array}{l}\text { Taxable } \\
\text { income }\end{array}$ & $\$ 30$ & $\$ 10$ & $\$ 24$ \\
\hline & - & - & - \\
\hline
\end{tabular}

In terms of taxable income, we may call Pattern A the Maximum, Pattern $\mathrm{B}$ the Minimum, Pattern $\mathrm{C}$ the Medium solution.

\section{Pattern A (Maximum)}

Pattern $A$, resulting in the maximum tax, is based on a merger of the two benefits. In common with the other two pre-1959 patterns, it treats the interest 
exemption as paramount. There is nothing taken away from the $\$ 20$ exemption of interest on state or municipal bonds.

The reserve deduction of $\$ 70$, however, may not be taken in full under this pattern. It is considered to such an extent a duplication of the interest exemption that it must be reduced, dollar for dollar, by the amount of that exemption. In other words, to the extent the company's earnings are anyhow tax-free, there is no need for a reserve deduction. Instead of $\$ 70$ only $\$ 70$ minus $\$ 20$ may be claimed as reserve deduction. The taxable income is therefore reduced from $\$ 80$ to $\$ 30$. The same amount- $\$ 30$-would be the taxable income of a taxpayer having no tax-exempt interest and being therefore entitled to the fuil $\$ 70$ reserve deduction from $\$ 100$.

This is the tax equity concept of the Revenue Act of $1921.0^{40}$ It found the support of many life insurance companies, the Court of Claims, ${ }^{41}$ and Justices Brandeis, Holmes, and Stone. In National Life Ins. Co. v. United States, however, a majority of the Supreme Court felt that "Congress had no power purposely and directly to tax state obligations by refusing to their owners deductions allowed to others." Assisted by the customary saving clause, the Supreme Court excised only that part of the 1921 Revenue Act that limited the reserve deduction to the excess of 4 per cent of the yearly mean of the company's reserve funds over wholly exempt interest. As a result, the Act had to be given effect as though the reserve deduction were 4 per cent of reserves for every life insurance company, regardless of any (additional) exemption of tax-free interest. As far as state obligations were concerned (federal government obligations were likewise involved), the decision was, of course, predicated on the doctrine of intergovernmental immunities. Its reasoning, as expressed in Justice McReynolds' opinion, is inspired principally by the net effect that, with all its tax-exempt interest, the company would have had to pay as much income tax as a company without any tax-exempt interest. Considering that the company had a substantial amount of tax-free interest, this could only mean that the truly taxable income (i.e., after eliminating the exempt interest) was encumbered with a heavier tax burden than in the hands of a company having no tax-exempt income-a discriminatory penalty for owning tax-exempt securities.

Justice Brandeis (joined by Justices Stone and Holmes) pointed out that the company had been given its full exemption for the tax-free interest. It was, in his opinion, not being discriminated against, since discrimination means different treatment for taxpayers in like circumstances, but not like treatment for taxpayers in unlike circumstances. ${ }^{43}$ (Justice McReynolds,

40. Ch. $136, \S 245,42$ Stat. 261 , defines "net income" of a life insurance company as gross income less (among other items): (1) interest on tax-exempt securities, (2) any excess of 4 per cent of the mean of the reserve funds required by law over the interest specified in (1).

41. National Life Ins. Co. v. United States, 63 Ct. Cl. 256 (1927), rev'd, 277 U.S. 508 (1928).

42. 277 U.S. 508,522 (1928).

43. Id. at 530 . 
sotto voice: ". . specious, but unsound").44 The constitutional exemption does not mean to guarantee that the holder of tax-exempt securities must in all tax respects be better off than the taxpayer holding no such securities. Yet even assuming that the abatement of the 4 per cent reserve deduction by tax-exempt interest is invalid, the remedy is not simply to strike the abatement. Congress might have wished to strike the entire reserve deduction.

Justice Stone, dissenting (joined by Justices Brandeis and Holmes), addressed himself to the doctrine of intergovernmental immunities in the light of his relativity theory. To him, the doctrine did not require Congress to grant benefits or immunities to a taxpayer only on condition that it extend the same benefits to holders of exempt securities in addition to their exemption. ${ }^{45}$ Instead of narrowing the exemption, the majority tended to expand it by reading into it an affirmative claim to favors.

\section{Pattern B (Minimum)}

Pattern $B$ recognizes no problem of duplication or overlap. If a company holds exempt bonds, it is entitled to the interest exemption. If it qualifies as a "life insurance company" in the technical sense, it is entitled to the reserve deduction. If it happens to fall into both classes, it is entitled to both benefits, cumulatively, even if they should add up to more than the taxpayer's total income.

National Life, in effect, so modified the 1921 Act and with a national economy heading toward unemployment and misery of catastrophic proportions, Congress had some more pressing problems to solve than to concern itself with the reserve deduction for life insurance companies-a question which would anyhow become academic with the expected general drop in earnings and, if approached with an excess of zeal, might engulf an entire basic industry in insolvency.

Thus, from National Life down to the most critical days of World War II, every revenue act left the Minimum solution untouched.

\section{Pattern C (Medium)}

If the term "medium" has the pleasurable connotation of a peaceful compromise on which all men of good will may readily agree, it is in the present connection ill-chosen. Pattern $C$, the most embattled of the three approaches, is the pattern over which battle is, once again, about to be joined. The principal reason for its provocative role is its chameleonic versatility. There is but one pattern $C$, if the criterion is the arithmetical result, but there are three, if it is the structure and even more if it is the reasoning that counts. Their underlying theme is the same-some sort of apportionment leading up to the same figure (24, in our example) - but it is a theme con variasioni. Each of these variations must be judged on its own merits. Their common theme

44. Id. at 520 .

45. Id. at 537 . 
-apportionment-neither saves nor condemns them. It is, therefore, desirable to expose them to at least a summary synopsis at this point.

Pattern $C(1)$, the variation described above, allows for the interest exemption first and in full. $\$ 100-\$ 20=\$ 80$. The reserve deduction comes next, and that in part only. The ordinary deduction of $\$ 70$ is reduced by an amount which bears to $\$ 70$ the same ratio as the tax exempt interest ( $\$ 20)$ bears to the entire investment yield $(\$ 100)$, that is, net investment income including tax-exempt interest. $20 / 100$ of $\$ 70$ being $\$ 14$, the reserve deduction is reduced to $\$ 70$ minus $\$ 14$, or $\$ 56$.

What is deemed to justify this reduction is the tax-free content of the credit to the reserves. The credit is being subjected to an assay. On the theory (equitable, to be sure, but nevertheless fictional) that the credit has proportionately the same components as its source (the investment income), 20 per cent of that credit is labeled "tax-free interest" and disqualified for the reserve deduction by reason of its prior elimination under the fully recognized interest exemption. The result is $\$ 100$ less ( $\$ 20$ plus $\$ 56$ ), or $\$ 24.45 a$

Pattern $C(2)$ likewise bows first to the untouchable exemption of interest. The step from $\$ 100$ to $\$ 80$ is still de rigueur. Ordinarily, the reserve requirement would absorb 70 per cent ( $\$ 70$ of out $\$ 100$ ) of net investment income (taxable or otherwise). But since there is no need for permitting a 70 per cent deduction for income which has already been removed from the collector's reach on grounds beyond challenge, the 70 per cent is applied only to the otherwise taxable portion of the income. 70 per cent of $\$ 80$ being $\$ 56$, the result again is $\$ 100$ less ( $\$ 20$ plus $\$ 56$ ), or $\$ 24.45 \mathrm{~b}$

Pattern $C(3)$ is the variation with a distinct preference for the unorthodox. Life insurance companies can survive without investing in tax-exempts. But they cannot continue their past and present way of computing their premiums without an assurance that the reserve requirements to be satisfied out of investment income are taxwise not "negotiable." Hence, the reserve deduction comes first and in full-all constitutional decorum notwithstanding. The $\$ 70$ reserve deduction lowers taxable income from $\$ 100$ to $\$ 30$. The legislator, however, may now have reason to tread with utmost caution. If he wishes to give tax-exempt interest its full due, he may feel that to the extent of 70 per cent of the interest the states have been given complete satisfaction, though under a different classification. Therefore, all that is required to satisfy a full 100 per cent exemption is a deduction of the remaining 30 per cent of the interest.

45a. Another version of the same method is to reduce $\$ 70$ by an amount which bears to the tax-exempt interest $(\$ 20)$ the same ratio as the reserve deduction $(\$ 70)$ bears to the investment yield $(\$ 100) .70 / 100 \times \$ 20=\$ 14$.

45b. As in Pattern $C(1)$, the principle of Pattern $C(2)$ may be given a different expression of similar rationale. Determine the ratio of the taxable portion to the total of the investment income. $\$ 100$ less $\$ 20=\$ 80: 100=80 \% .80 \%$ of $\$ 70$ is the reserve deduction $(\$ 56)$ which reduces the taxable portion $(\$ 80)$ to the amount representing the company's taxable income. In this manner the nontaxable as well as the taxable portion of the earnings on the reserve is forced to carry its load of the credit to the policyholders. 
Thus, deduct from $\$ 30$ an amount equal to 30 per cent of $\$ 20$, or $\$ 6$-and, once again, the result is $\$ 24$.

Of these three variations of Pattern $C$, all (at one time or another) have appeared on the federal scene. The second variation, although condemned by many companies as discriminatory, ${ }^{46}$ governed (either explicitly or in practical effect) for some 16 years (1942-1957) for federal income tax purposes. ${ }^{47}$ With a generous reserve deduction level of 85 to more than 100 per cent of taxable net income, however, its operation under the 1942 formula and its stopgap successors was of so negligible effect that it aroused at that time no resistance. ${ }^{48}$ The third variation, embodied in the 1959 Act, still is awaiting its day in court.

The validity of variations one and two has been tested, however, in cases involving state property taxation. A few years before National Life, a Michigan property tax law was submitted for examination by that state's courts in Packard Motor Car Co. v. City of Detroit, and was found wanting. ${ }^{49}$ The statute purported to tax "credits" (read: bonds, claims, certificates of indebtedness) less debts owed, but if the taxpayer owned "credits" exempt from tax, debts were deductible only in the same proportion as taxable "credits" bore to total "credits." The taxpayer had total "credits" of $\$ 18$ million, of which $\$ 12$ million were exempt. Its debt amounted to $\$ 9$ million. If $\$ 12$ million could be entirely eliminated as exempt, there would be a debt of $\$ 9$ million against taxable assets of $\$ 6$ million, hence no tax. The law called for apportionment. Only $6 / 18$ ths of the debt was deductible if only $6 / 18$ ths of the credits was taxable. On this theory $\$ 3$ million remained taxable. The apportionment theory was held erroneous, and the law void. "In laying a tax on property, tax exempt credits must be treated as nonexistent. The legislature may not make use of, or permit consideration to be taken of, tax exempt credits as a factor in determining taxes to be paid by holders thereof." 50

46. Hearings on H.R. 4245 before Senate Finance Committee, 86th Cong., 1st Sess. at 310-11 (1959).

47. Omitting factors which are of no relevance to our problem, the 1942 formula is, in essence, a fraction-the numerator of which is adjusted reserves times earnings rate (the $\$ 70$ reserve requirement) and the denominator of which is net income before reduction of tax exempt interest (the $\$ 100$ figure in our example). Int. Rev. Code of 1939, $\S 202$ (b) (1), as amended, [Revenue Act of 1942] ch. 619, $\$ 163,56$ Stat. 870 (1942). Elimination of duplicate deductions was stated as a specific reason for enacting the formula. See H.R. REp. No. 2333, 77th Cong., 2d Sess. 27 (1942) ("a formula which has the effect of ... eliminating the double deduction of tax exempt interest").

48. According to a statement by Mr. Stanford Z. Rothschild, president of the Sun Life Insurance Co. of America, Hearings at 695, the absence of opposition is attributable to the fact that the 1942 formula took into account the industry's average holdings of exempt securities, favoring in effect the companies with above-average amounts of taxfree interest (i.e. those otherwise most likely to complain) and placing at a disadvantage the companies with less than average tax-exempt interest.

49. 232 Mich. 245, 205 N.W. 106 (1925) ; Packard Motor Car Co. v. City of Detroit, 232 Mich. 250, 205 N.W. 108 (1925).

50. 232 Mich. at $247 ; 205$ N.W. at 107. 
Clearly, this decision of a state court condemns our variation (1) of Pattern $C$, because what the law required was to reduce our $\$ 70$ by so much of itself as exempt "credits" bore to total "credits," i.e., 20/100. Needless to add, this ruling met with the wholehearted approval of the majority in National Life. ${ }^{51}$

In the second case testing Pattern $C$, Missouri ex rel. Missouri Ins. Co. v. Gelmer, ${ }^{52}$ a Missouri state law imposed a property tax on the net value of all property of insurance companies in excess of the legally required reserve. The Missouri Insurance Company had $\$ 142,000$ in real property and $\$ 448,000$ in personal property of which $\$ 94,000$ were exempt federal government bonds. Its legally required reserve was $\$ 333,000$. The company deducted from $\$ 448,000$ both the $\$ 94,000$ United States bonds and the full reserve and claims liability of $\$ 333,000$, a total of $\$ 427,000$, and arrived at a taxable personal property of $\$ 21,000$.

The Missouri Supreme Court took exception to this computation. ${ }^{53}$ It required the company to add up all taxable property, real and personal, and to divide the sum $(\$ 496,000)$ by its total assets, including the nontaxable $\$ 94,000$ in United States bonds $(\$ 590,000)$. The percentage so determined ( 84 per cent) was then to be applied to the reserves and claims $(\$ 333,000)$, and only the resulting figure $(\$ 280,000)$ was to be deducted from the taxable personal property. So computed, the taxable personal property was $\$ 74,000$, instead of $\$ 21,000$.

A majority of the United States Supreme Court held this state law construction to violate the rule of National Life:

[A] State may not subject one to a greater burden upon his taxable property merely because he owns tax-exempt government securities. Neither ingenuity in calculation nor form of words in state enactments can deprive the owner of the tax exemption established for the benefit of the United States. [Citing National Life and cases cited in McCulloch v. Maryland.]

The section discloses a purpose as a general rule to omit from taxation sufficient assets of the insurance companies to cover their legal reserve and unpaid policy claims. It would be competent for the State to permit a less reduction or none at all. But where as in this case the ownership of the United States bonds is made the basis of denying the full exemption which is accorded to those who own no such bonds this amounts to an infringement of the guaranteed freedom from taxation. It is clear that the value of appellant's government bonds was not disregarded in making up the estimate of taxable net values. That is in violation of the established rule. ${ }^{54}$

Chief Justice Hughes concurred on the basis of National Life.

Justice Stone (joined by Justices Brandeis and Holmes) did not revert to his dissent in National Life. He felt that the majority was in error even if

51. 277 U.S. 508, 520 (1928).

52. 281 U.S. $313(1930)$.

53. 322 Mo. 339, 15 S.W.2d 334 (1929).

54. 281 U.S. at 321. 
National Life were conceded to be correctly decided. "The immunity of government bonds from taxation does not carry with it immunity from liability for debts." "פ5 Liabilities must, therefore, be deducted from all assets, including exempt bonds, "or, what comes to the same thing, by deducting from taxable assets their proportionate share of the burden of policy liabilities.... In fact and in law tax-exempt securities constitute a part of the corporate reservoir of capital, all of which without distinction may be drawn on for the payment of obligations." 50

The Missouri case differs, of course, in a number of respects from the issue here under discussion. It must be translated from property to income, from state to federal taxation, and from federal to state or local bonds. Its essence, however, clearly adopts the minimum solution of Pattern $B$ as the proper pattern of coexistence. Its particular significance lies in the conclusion most heartening to the companies that the minor infraction by apportionment still remains an infraction in the eyes of the Supreme Court. The rejected pattern of coexistence was, it should be noted, the property-tax counterpart of the second variation of pattern $C$, the variation employed by the federal statute from $1942-1957 .{ }^{57}$

\section{Coexistence Under the 1959 Act}

\section{The House Method of Avoiding Duplication}

With a retrospective glance at a sixteen-year record of avoided duplication, introduced with the industry's advice and consent, the House had no reason to be tentative about the interplay of the two immunities, when it passed H.R. 4245 on February 18, 1959.

Taxable Investment Income was defined as net investment income minus the "policy and other contract liability deduction," which we have called the "reserve deduction," since its primary component is the deduction for the earnings attributable to the (adjusted) life insurance reserves. ${ }^{58}$ In reducing investment income (which included tax-exempt interest) from gross to net, full deduction was granted for wholly tax-exempt interest. ${ }^{59}$ However, unless corrected, the reserve deduction would reflect the investment earnings in their entirety, regardless of taxability. Hence an "adjustment to prevent double deductions" was required..$^{60}$

In its essence, ${ }^{61}$ the adjustment called for an "adding back" of the same proportion of the wholly tax-exempt interest as the reserve deduction( before

55. Id. at 324 .

56. Id. at 323-24.

57. See text at note 47 supra.

58. H.R. 4245, 86th Cong., 1st Sess. § 805 (a) (1959).

59. Id., § 804 .

60. Id., $\$ 805(\mathrm{c})$.

61. Omitting such other elements as partially exempt interest, dividends received, investment yield on pension plan reserves, the small business deduction, which all enter into the adjustment formula but do not affect the principle as applied to wholly taxexempt interest. 
this adjustment) was of the "investment yield," that is, of the net investment income before deducting tax-exempt interest. Thus, if a company is required to add to reserves an amount equal to 70 per cent of its net investment income (before deducting tax-exempt interest), ${ }^{62}$ and the net investment income of $\$ 100$ includes $\$ 20$ wholly tax-exempt interest, the reserve deduction was to be not $\$ 70$, but $\$ 70$ minus seven-tenths of $\$ 20$ ( $\$ 14)$, or $\$ 56$, which is equal to the full 70 per cent on the taxable part of the income, $\$ 80$. This method adopts the principle of Pattern $C$, first variation.

The possibility that this curtailment of the reserve deduction by reason of a company's investment in tax-exempt securities might trespass into a politically sensitive area did occur to the draftsmen, but it must have been considered as too farfetched to be worthy of more than a passing remark for the benefit of unduly apprehensive members of Congress. "This does not, however, impose any tax on the exempt interest ..." is their reassuring, if somewhat terse, comment. ${ }^{63}$

\section{The Pilgrims' Chorus}

The companies took a less detached view of the proposed adjustment, the intensity of their objections varying presumably in degree with the extent of their present and contemplated investment in tax-exempt securities. To them, there was not only a deviation from the existing law, but an ominous invasion of the sanctuary of tax-free interest, which well might end in its complete destruction, a collateral attack only a trifle milder and more subtle than the abomination perpetrated by the 1921 Revenue Act and rightly scrapped by an indignant majority of the Supreme Court as rank discrimination. ${ }^{64}$ The spectre of a deliberate reversion to the lawlessness of the early twenties set in motion an impressive pilgrimage to Washington.

It seems to be in the nature of legislative hearings that even grievances of a primarily legal and technical nature must be pleaded with all the fervor of campaign oratory. In this case, the "widows and orphans," 65 the "over 100 million small savers," questionable analogies with other groups of taxpayers, and similar irrelevancies have tended to obscure the true merits of an objection which is difficult enough to evaluate without the benefit of rhetorical surplusage.

A noticeably appreciative and sympathetic Finance Committee, eager to be enlightened by both sides on a troublesome point of constitutional law (the policy of retaining, on principle, both the reserve deduction and the exemption of interest on municipals was at no time at issue), was left without the founda-

62. For purposes of simplified illustration the 70-per cent figure is frequently used in this discussion, as it has been in the hearings before the Senate Finance Committee, although it is but a rough approximation of the average.

63. H.R. REP. No. 34, S6th Cong., 1st Sess. 11 (1959).

64. National Life Ins. Co. v. United States, supra note 41.

65. Hearings at 317.

66. Id. at 307 . 
tion on which to base an informed legal judgment of its own. Much was said about the threatening collapse of the market in municipals and its effect on state finances, or about past practice under the 1942 and subsequent formulae, when the reserve deduction was so high and the investment yield so low that the tax was minimal or (as in 1947 and 1948) nonexistent. Little or nothing, however, was heard about the present authority of Supreme Court cases handed down some 30 years ago when vested rights commanded a different kind of respect ; or about changed judicial thinking in matters of intergovernmental immunities; or about the power of Congress to classify taxpayers in accordance with the peculiar characteristics of their economic functions.

The unfortunate result was a nebulous compromise in an otherwise remarkably thorough, constructive, and comprehensive piece of legislation-an oracle in the place of an order.

\section{Suum Cuique or Justice With Malice Aforethought-The Senate Amendment}

It was no easy drafting assignment to cast the Finance Committee's nice balance of firmness and fairness into a legal mold equipped to pass the acid test of judicial proceedings. The draftsmen rose to the occasion.

Here were lachrymose plaints voiced on behalf of poor widows and orphans and over 100 million small savers, and with understandable pride did the companies point out that "close to $\$ 1$ billion of Policyholders' Funds are invested in turnpike and toll road bonds and in financing educational facilities, primarily through state and municipal bonds. . ."'67 Could there be anything more gratifying to the companies than to have their wards recognized, officially and de jure, as the proper parties in interest? And would not such recognition automatically solve in the most convincing and plausible manner the problem of the tax-exempt interest, since the exemption naturally belongs to those recognized as being entitled to the interest?

Exit the old-fashioned concept of a reserve deduction. Instead, the company will divide its net investment "yield" (which term always means "including tax-exempt interest") into two neatly separated shares. One, now boldly called "the policyholders' share," is outside the company's taxable investment income. It is excluded. The other is the company's own share, the only portion for which it must account to the tax collector. ${ }^{68}$

Call it a magician's trick, or a stroke of genius-it is as stunningly plain a solution as Columbus' fabled way of making an egg stand up, simply by crush-

67. Instrtute of Life Insurance, Life Insurance Fact Book 1959 at 69. (Emphasis added.)

68. In providing for the division between policyholders and the company, Congress adopted a "personalized" approach reflecting the individual requirements of each company. Of necessity, compliance with this fundamental policy means, and results in, a more complex statutory formula for what may briefly be called the "reserve deduction."

As focused upon wholly tax-exempt interest, the law contemplates mainly two steps designed to implement the partition. The first step is to compute the policyholders' share of "ẹach and every item of investment yield" (a term which includes tax-exempt interest). 
ing it gently at one end. All the noisy dispute over a "cut" in the reserve deduction is now a matter of the past. The deduction has been promoted to the rank of a full-fledged exclusion, and it is granted with no strings attached.

On the contrary, in giving the deduction, now exclusion, its effect on both the company and the policyholders as a group, the law displays an extraordinary degree of thoroughness. The policyholders' share is not merely a portion, say 70 per cent, of the aggregate, in terms of dollars and cents. With an emphasis and redundance quite unusual in statutory language, the Act grants to the policyholders a "share of each and every item of investment yield (including tax-exempt interest ....)." 69 This piece of nuclear physics, subjecting "each and every item" to an imaginary fission-like split into a policyholders' and a company's share, is considerably more than a startling technical innovation. It is the unequivocal denial of the companies' claim to the full exemption of their tax-free interest. The magnanimous gesture of charging them with only a 30 per cent "share" of the earnings, coupled with the merciless fission of "each and every" item, logically enough bars them from claiming more than their 30 per cent "share" of the statutory interest exemption.

In terms of dollars-leaving aside the legal analysis-this means a reaffirmance of the status quo. Using our illustration, the House version would have given the company the full $\$ 20$ exemption for tax-free interest, but would have reduced the reserve deduction from $\$ 70$ to $\$ 56$, leaving the company with a taxable income of $\$ 24$. As enacted the 1959 Act gives the company, instead, the full exclusion of $\$ 70$, but reduces the interest exemption to 30 per cent of $\$ 20$, or $\$ 6$, resulting in a taxable income of, once again, $\$ 100$ minus $\$ 76$, or $\$ 24$.

This third variation of Pattern $C$ thereby maintains the continuity even with the more remote past, the formula of 1942, the prototype of the second variation of the same pattern. ${ }^{70}$ Words and theories have changed, and so have

The policyholders' share generally is the percentage obtained by dividing the policy and other contract liability requirements by the investment yield. See text accompanying notes 33-37 supra.

Depending on the relationship between a company's actual investment yield and the amount necessary to maintain the reserves, elements which will vary from company to company and from year to year, the policyholders' share will absorb a more or less substantial part of the investment yield. The Code itself anticipates that it may amount to as much as $100 \%$-wherever the policy requirements exceed the actual investment yield of a company. Inr. Rev. Code of 1954, $\$ 804$ (a) (1). The discussions before the Senate Committee speak of 70 and $75 \%$ of net investment earnings as a likely average. Hearings at $49,309$.

The policyholders' share, so computed is then excluded from the taxable investment income of the company. INT. Rev. CoDE of 1954, \& 804(a) (1).

The second step is to add up the company's shares of each item of investment yieldthe balance remaining after the exclusion of the policyholders' shares-and to reduce the sum by the company's share of the fully tax-exempt interest (and of other items not here pertinent). INT. REv. CoDE of 1954, $\$ 804$ (a) (2).

69. InT. Rev. Code of 1954, § 804(a) (1), as amended, 73 Stat. 115 (1959).

70. See text at note 47 supra. 
the battle line and the battlefield, which remain to be surveyed. Yet, looking at the purse effect only, it is as the sceptical French never tire to remark: "Plus ça change, plus c'est la même chose!"

\section{Testrng the New Law \\ Legislation With a Postscript}

Facing the severe amputation of their interest exemption under the 1959 Act, those companies with a substantial stake in tax exempts ${ }^{71}$ may seek refuge in the one manifestation of Congress which on its face would seem to respond to the companies' fervent prayers in the pre-enactment stage-a thoroughly enigmatic postscript to the elaborate technical pattern. It reads:

If it is established in any case that the application of the definition of taxable investment income contained in paragraph (2) results in the imposition of tax on-

(A) any interest which under section 103 is excluded from gross income,

adjustment shall be made to the extent necessary to prevent such imposition.72

Some companies like to take a highly optimistic view of this mysterious postscript. Perhaps they find some encouragement in the Finance Committee's Report: "In addition, your committee's bill by a special proviso makes it clear that in no case is any tax to be imposed on tax-exempt interest . . .".73 To these companies nothing would appear to result as evidently in the imposition of a tax on tax-exempt interest as the unequivocal and unconcealed denial to the companies of the exemption allocable to the policyholders' "share."

Tactfully refraining from too close an examination of a gift horse, the companies are inclined to overlook the extremely limited scope of what they like to consider as a kind of magna charta guaranteeing their vested rights. The

71. The life insurance fraternity is as divided in its attitude to the 1959 Act as it was when National Life challenged the 1921 Act, and won. The "loyalists" who, represented by the later Chief Justice Charles E. Hughes, sided with the government under the 1921 Act as anici curiae included many of the giants who endorsed F.R. 4245 when Senator Byrd introduced it on the floor of the Senate, see 105 CoNG. REc. 8400-02 (1959) (Senator Byrd's explanatory statement of May 19, 1959). Whether that impressive group has, in addition to more enlightened public relation departments, also better prophets in its legal departments than the "rebels," remains to be seen.

72. INT. Rev. Code of 1954, \$ 804(a) (6), as amended, 73 Stat. 116 (1959) (italics added). See also INT. Rev. Cone of 1954, $\$ 809$ (b) (4). The only point in this ambiguous postscript amplified by the Proposed Treasury Regulations is the phrase "if it is established in any case." The regulation reads, "If it is established . . . to the satisfaction of the Commissioner, or by a determination of the Tax Court of the United States, or of any other court of competent jurisdiction, which has become final, that the application ...." Treas. Reg. \$ 1.804-2(e) (1), 25 Fed. Reg. 7990 (Aug. 18, 1960).

73, S. Rep. No. 291, 86th Cong., 1st Sess. 18 (1959). 
Finance Committee Report calls the postscript a "special proviso." The act itself is more to the point in calling it an "exception."74 Both designations are ample warning that this is not the proper platform on which to challenge anything as basic and generally applicable as the recognition, in form as well as in substance, of the policyholders as investors. To those who do not believe in mere headings, there is an equally perturbing caveat in the introductory "if it is established in any case ...." The "exception" is as deliberately vague about the conditions under which it may be invoked as it is with respect to the method of corrective action. Nevertheless, the phraseology points to the peculiarities of applying the formula to the taxpayer's particular case, as distinguished from an attack on fundamental principles which form one of the most significant innovations of the 1959 Act, applicable with equal force to all taxpayers in a similar position.

Nor is it the proviso's function to salvage the remainder of the Act, by means of a built-in correction, should a court object to the new definition of taxable investment income and its "confiscation" of the exemption to the extent of our hypothetical 70 per cent. There is a perfectly adequate separability clause in section 7852 (a) of the Code.

If more were needed to expose the largely decorative purpose of the "special proviso," it might be suggested to take a closer look at what a taxpayer is allowed to "establish," in order to assert a claim for corrective adjustment. The company would have to establish that in its case the application of the "taxable investment income" definition "results in the imposition of tax on" tax-exempt income.

There is a distinctly diabolic touch to this requirement. In turning its face to Congress, the proviso seems obsequiously to say: "Everything is in accordance with your wishes, gentlemen. Nobody is being hurt. Municipals are exempt, and to make assurance double sure, we will give satisfaction to any taxpayer proving that his municipals are being taxed." This diplomatic objective being accomplished and reassuringly echoed by the Report, as quoted above, the proviso turns to the taxpayer in a more pugnacious mood: "Now you show us, if you can, how your municipals are being taxed. Seventy per cent of the interest belongs to the policyholders, who are taxpayers strictly honoris causa, since they pay no current taxes on it anyhow and for all the law provides may never have to pay a tax on that money. Thirty per cent is yours and that is specifically freed from tax. How much more than one hundred per cent exemption on that interest do you expect us to allow?" The paraphrase, while not anticipated by Congressmen untrained in the interpretation of oracles, is, of course, unanswerable. No tax is being imposed on taxexempt interest, if it is true that 70 per cent of the interest does not belong to the companies.

Whether the law properly and validly treats the policyholders as the recipients of 70 per cent of the investment income, or whether it thereby indulges

74. INT. REv. CODE of 1954, $\S 804$ (a) (6), 809(b) (4), as amended, 73 Stat. 115, 121 (1959). 
in a fiction much like the communists' claim that in Russia the factories belong to the workers-that key question is clearly beyond the ken of the "special proviso." It is not to be answered by establishing the facts of any one individual case, but a challenge to the validity of the law in general.

The companies can attack the statute, therefore, only by challenging the authority of Congress to ascribe 70 per cent of investment income to the policyholders. If they succeed, they have shown that 70 per cent of their tax-exempt interest has not been given the statutory tax exemption. In this event, counsel for the Treasury will be powerless to defend the statute. He cannot request the court to reexamine the constitutional doctrine of tax-exempt interest, for whether or not the Constitution requires an exemption for municipal bond interest, Congress in the legislative history and in the postscript itself has made abundantly clear its desire to preserve that exemption as a matter of legislative policy. ${ }^{75}$ Thus the court would be faced with a selfcontradictory statute. If the court believes that the 70 per cent of investment income cannot be allocated to the policyholders, it must ignore either the statutory apportionment or the congressional intent to respect the interest exemption. This dilemma is reminiscent of the classic case in which a donor made what he deemed to be a tax-exempt gift, but declared his gift to be revoled if the courts should hold it taxable-a kind of trifling with the judicial process for which the court in that case showed little liking. ${ }^{76}$

\section{Debtor or Conduit}

Given an abundantly documented congressional promise of an unabridged municipal-interest exemption, and finding themselves left with a statutory exemption for only, say, 30 per cent of that interest, the companies will wish to take a closer look at the technique of this amazing vanishing act. The arithmetics of the Treasury's case alone appear to be adequate reason for invoking

75. Under these circumstances, the courts are not confronted with the present validity of Pollock v. Farmers' Loan \& Trust Co., 157 U.S. 429 (1895), rev'd and remanded on rehearing, 158 U.S. 601 (1895), which treated a tax on bond interest as a tax on the bond, a theory declared to be no longer tenable after Graves v. New York ex rel. O'Keefe, 306 U.S. 466 (1939), overruling Collector v. Day, 78 U.S. (11 Wall) 113 (1870). Nor is it material whether the immunity principle, once it is applicable, applies absolutely, Indian Motorcycle Co. v. United States, 283 U.S. 570 (1931) ; McCulloch v. Maryland, 17 U.S. (4 Wheat.) 316 (1819), or only where the interference with the state function is shown to be actual and substantial, not purely conjectural, Helvering v. Gerhardt, 304 U.S. 405, rehearing denied, 305 U.S. 669 (1938). For the possible effect of the public salary cases on the constitutional protection of state bond interest, see e.g., Knollenberg, Book Review of The Constitutronal Imsirunity of State and Municipal Securities, 49 Yale L.J. 158 (1939).

As was said in Estate of Alexander J. Shamberg, 3 T.C. 131 (1941), aff'd, 144 F.2d 998 (2d Cir. 1944), cert. denied, 323 U.S. 792 (1945), there is no need for passing upon the doctrine of intergovernmental immunities until Congress sees fit to remove the protection afforded by the statute.

76. Commissioner v. Procter, 142 F.2d 824 (4th Cir. 1944), cert. denied, 323 U.S. 756 (1944). 
National Life and Missouri ex rel. Missouri Ins. Co. v. Gehner. Since the result is invariably the same Medium figure of $\$ 24$, whether a full reserve deduction ( $\$ 70$ ) is added to a mere $\$ 6$ as tax-exempt interest (as in the 1959 Act), or whether a full interest exemption $(\$ 20)$ is added to a mere $\$ 56$ reserve deduction, it is obvious that the 1959 Act consciously and deliberately rejects the Minimum figure of $\$ 10$ called for under the Supreme Court's decisions. The Treasury might wish to argue that in National Life the Court struck down only an insidious and ill-concealed attempt to nullify the interest exemption by clipping the reserve deduction, whereas the 1959 Act allows the full reserve deduction and is quite candid about the decimated interest exemption. Yet it is clear that the Supreme Court did not intend to sit in judgment over a question of legislative ethics alone. It emphasized the realities, the mathematical result, and must therefore be understood to have ruled out any merger whatever of the two immunities, no matter which is being assigned the role of the survivor. And if moralities must enter into the picture, both decisions amply reflect judicial indignation at any overly ingenious method of calculation or drafting.

The companies' point of departure therefore rests on solid ground. It is further strengthened by the fact that under any aspect of property law the companies hold undisputed title to the bonds, collect the interest thereon without any duty to account, and as a matter of finances are the persons whom the borrowing states or municipalities must regard as the lenders. While it is true that the companies must give the policyholders their "due," the credit to reserves set aside for policyholders should, at worst, be treated as a form of spending or applying the companies' own income, a kind of interest, a fulfilment of the "interest" guarantee worked into the premium. If interest deductions are allowed other taxpayers, ${ }^{77}$ such as banks or industrial corporations, without cutting into the exemption which they enjoy by reason of holding state or municipal securities, there is no reason for discriminating against life insurance companies merely because their "interest" deduction is being recognized in the particular form of a reserve deduction (exclusion). That form merely eliminates the theoretical question whether there can be an "interest" deduction where really there is no "indebtedness," for want of maturity of the policy. ${ }^{78}$ In any event, the companies' commitment to the policy-

77. The allowance of an interest deduction-there is no statutory question of disallowing the exemption of state or muncipal bond interest-is denied only if the indebtedness was incurred or continued to purchase or carry exempt obligations. INT. REv. CoDE of $1954, \S 265$. An investment resulting from the sale of a policy or a commitment to build up a policy reserve is by its nature, motive and business purpose outside this disqualified category.

INT. REv. CODE of 1954, $\$ 818$ (f), an accounting provision of old standing, precludes the deduction of the same item more than once. An item going out as accrued "interest" on the book reserve of a policy can hardly be identical with an item coming in as interest on the company's investments-unless the company is not merely a "financial institution," but a pipeline.

78. Duffy v. Mutual Benefit Life Ins. Co., 272 U.S. 613 (1926) ; see Penn Mutual Life Ins. Co. v. Commissioner, 92 F.2d 962-67 (3d Cir. 1937); Commissioner v. Pan- 
holders is at most an obligation to credit the policyholders with a certain amount in terms of dollars, not to pass on to them a proportional amount of every item of investment income earned by the company. The commitment is not in the nature of a mortgage on, or pledge of, company earnings-it would exist even if a company decided not to invest at all-and therefore it takes nothing away from the companies' unquestioned right to the bond interest.

The equities of the companies' grievance are prima facie impressive. The opportunity for asserting them in judicial proceedings, however, is extremely restricted. The legislator is no longer in the process of deliberating policy. $\mathrm{He}$ has devoted much time to that phase and has now spoken his final, "I will it." Thus, except for the very limited scope of the nebulous "postscript,"70 the companies' attack must proceed from "dehors the instrument," so to speak.

The reduction of the interest exemption from 100 to 30 per cent or less is not a matter of statutory construction or misconstruction. It is a deliberate decision of Congress. Had Congress done nothing more than to announce this decision, maybe it would have done nothing more than to invite a reexamination of National Life and the Missouri Ins. Co. case renouncing in advance any benefit to be derived from the present punctured condition of the intergovernmental immunities doctrine which was the backdrop for those decisions. The question before the Court then would call merely for a determination whether applying the reserve deduction to the interest exemption was just as objectionable as applying the interest exemption to the reserve deduction-the mathematical result being the same, on this occasion the passage of some 30 eventful years of tax administration might or might not give the Supreme Court pause to reconsider the intrinsic merits of the precedents and the present-day validity of their message, highly controversial as they have been from the very day of their promulgation.

Yet, put on notice by the extensive hearings before the Senate Finance Committee, Congress was determined not to expose itself to a mere revival of National Life and its unhappy ending. It took the unusual precaution of incorporating into the law what ordinarily it might have left to the skill of counsel to detect and expound-its motives and line of reasoning. It wrote a brief justifying the trimming of the interest exemption, but it endowed it with the weight and authority of a duly enacted law. For income tax purposes, it made of the life insurance company a personality split between acting for others and acting for itself, a kind of conduit, if not fiduciary, for most of its earnings. Rather than denying a share of the exemption because of duplicate

Am. Life Ins. Co., 111 F.2d 366 (5th Cir.), aff'd, 311 U.S. 272 (1940); Equitable Life Ass'n Soc'y v. Helvering, 137 F.2d 623 (2d Cir. 1943), aff'd, 321 U.S. 560 (1944); New England Mut. Life Ins. Co. v. Welch, 153 F.2d 260 (1st Cir. 1946).

79. The proviso may have some application to a foreign life insurance company investing in bonds issued by American states or muncipalities. See Manufacturers Life Ins. Co., 32 F. Supp. 284 (1940), 43 BTA 867 (1941). 
benefits, Congress has denied 70 per cent of the interest exemption because 70 per cent of that income does not belong to the companies.

This theory is more than the "ingenuity in calculation" or "form of word" for which the Supreme Court displayed aversion in National Life. ${ }^{80}$ Congress enacted the 1959 Act based upon a new and previously untested premisethe conduit theory. Since this rationale is backed by the force of law, the companies must wrestle with the Act as it is written, and this involves the formidable task of demonstrating that the conduit theory is not merely inaccurate or unwise, but arbitrary, whimsical, despotic, or at least a discriminatory form of classification. ${ }^{81}$

This burden is neither met nor obviated by the assertion that the exemption belongs to the company in full as of right because it cannot be divorced from the legal ownership of the bonds and the uncontested right to collect the interest. The law takes, and always has taken, a different view. Long before any doubt was cast on the sanctity of intergovernmental immunities, courts have faced a variety of situations involving the need for a distinction between the "right" and the "wrong" person to claim the exemption. The exemption is a commitment to the state governments, of which commitment, whether constitutional or statutory, the taxpayer is but the "tertius gaudens," the thirdparty beneficiary. Who the proper taxpayer is, is a question of federal tax law which is not a part of the commitment. In individual borderline casespledged securities, repurchase options, securities transferred to a trust which in turn issues interest-bearing participating certificates-the courts have determined the question of qualification, generally on the basis of the parties' intentions, beneficial interest, and the economic purpose of the transaction, rather than legal title. ${ }^{82}$ There is no reason for denying the same authority to Congress for such typical situations as it deems a proper subject of more general legislation, provided it exercises its power within the limits of reason.

The Internal Revenue Code, in its general provision of section 103, says nothing about the person entitled to the claim for exemption. In this respect it is more reticent than on other "items specifically excluded from gross income," $"$ such as gifts, inheritances, death benefits under life policies, where the addition of the words "received" or "acquired" gives at least a more specific indication of the taxpayer eligible for the benefit. While this silence seems to reflect a kind of neutral "to whom it may concern" attitude, the

80. See National Life Ins. Co. v. United States, 277 U.S. 508, 519 (1928) ; Missouri ex rel. Missouri Ins. Co. v. Gehner, 281 U.S. 313, 321 (1930).

81. For a detailed discussion of the constitutional limitations upon the taxing power of Congress, see 1 MIERTENs $\$ 4.09$.

82. Carson Estate Co., 31 BTA 607 (1934), aff'd per curiam, 80 F.2d 1007 (9th Cir. 1936) ; Bess Schoellkopf, 32 BTA 88 (1935), taxpayer's appeal to CCA-5 dismissed, August 25, 1936; Norfolk Nat'l Bank v. Commissioner, 66 F.2d 48 (4th Cir. 1933) ; First Nat'l Bank v. Commissioner, 57 F.2d 7 (10th Cir. 1932), affirming 19 BTA 744, 750 (1930), cert. denied, 287 U.S. 636 (1932) ; Commissioner v. The Bank of Ca1., 80 F.2d 389 (9th Cir. 1935), affirming 30 BTA 556 (1934); G.C.M. 12355, CB XII-2,100.

83. Title of Subchapter B, Part III, INT. REv. CODE of 1954. 
context, that is, the close connection with other exclusions, leaves no doubt about the taxpayer who qualifies. There can be no exclusion of income, unless without it there would have been an inclusion, and, subject to the exclusions granted by law, a taxpayer is accountable for "all income from whatever source derived." 84

It is at this point that the 1959 Act intervenes. Under the heading "exclusion of policyholders' share of investment yield" the Act implies that a certain percentage of the company's investment income (including tax-free interest) is chargeable to the policyholders, and therefore "shall not be included" in the company's taxable investment income. ${ }^{85}$ It aligns itself with the long list of other exceptions to the principle of section 61 .

Congress is of course limited in awarding the exemption by the constitutional requirement that it refrain from acting arbitrarily or unreasonably. For example, it may be arbitrary and unreasonable to provide that if an individual taxpayer invests his savings in municipal bonds, the exemption should be given not to him but to his grandmother. Yet suppose a taxpayer had received bonds from his grandmother as a gift, with the understanding that she receive periodically 70 per cent of the interest earned for the rest of her life. Would it be unreasonable and arbitrary for the law to split the exemption 70-30 between the two? Or would it become unreasonable if, under otherwise similar circumstances the bonds had been bought by the taxpayer on his own initiative in investing or reinvesting funds received from grandmother in cash? Could the party most directly interested, the municipality-if it were in a position to be heard -allege an impairment of its borrowing power by reason of the split, whether or not, on some personal ground, grandmother was exempt from federal tax and, therefore, the interest exemption wasted on her?

The classification of policyholders as income recipients (and thereby recipients of the tax-exempt interest) must undergo the same test of reason. If this is a reasonably possible classification, it is irrelevant whether it is, by scientific standards, right or wrong. And it is beyond the competence of courts to decide whether it is good or bad as a matter of legislative policy.

For decades Congress has underwritten the states' regulatory and elaborately enforced requirement of a systematic build-up of actuarially needed life insurance reserves. The reserve deduction and allowances of similar effect, designed to implement this policy, were the federal government's recognition of the special needs of the life insurance industry as a separate group of taxpayers. These needs were determined by the companies' operation under state control as media for the pooling and investment of money contributed by the policyholders, as actuarially required with a view to the systematic accumulation of the funds necessary for their mutual insurance. Investment is an indispensable element of that function, but to the extent to which it serves to strengthen the reserves, it is insurancewise the undertaking of the policy-

84. INT. REv. CoDE of 1954, § 61(a).

85. INT. Rev. Code of 1954, § 804(a) (1), as amended, 73 Stat. 115 (1959). 
holders as a group. The legal form of insurance is a contractual obligation of the company to the individual policyholder, and if this aspect were applied to the prematurity stage it would tend to bespeak a mere debtor-creditor relationship between the company and its policyholders with regard to the process of setting aside the requisite dollar amount as additions to reserve. The economic essence, however, as reflected in the computation of premiums and the state-supervised formation of reserves, is a joint venture of the largest possible number of participants. It is these participants, the policyholders, who bear the true and ultimate insurance risk. "For it must always be kept in mind that insurance losses are paid by the policyholders themselves and by no one else."86 It is for their benefit as mutual insurers that the state maintains close surveillance, checking not only on the accounting to reflect the growth of the future liability to the policyholder, but also on the actual presence of the assets necessary, as of any time, to meet it. It is for their benefit, also, that Congress abstains from taxing the investment earnings on the reserves.

If under most favorable circumstances no less than 70 per cent, and in a less auspicious climate as much as 100 per cent, of the company's investment earnings are needed for legally required additions to reserves for policyholders, and if more than 82 per cent of the vaunted $\$ 107$ billion in total assets of United States life insurance companies represent aggregate policy reserves, ${ }^{\mathbf{8 7}}$ there is, as a matter of economics and therefore of tax law, definite room for the question: Whose business is it? Who is the principal?

The 86th Congress did not like the noncommittal answer of prior legislation which was interested only in limiting the amount of the reserve deduction, but as to its nature permitted the inference that it was a kind of business expense, or interest on borrowed funds, in any event nothing more than a monetary obligation of the company. Instead, it attributed to the company a fiduciary-like status vis-à-vis the policyholders, a legal duty to pass on to them the very earnings on their contributions.

This view is in line with the thinking of judicial, tax, and insurance authorities throughout the past few decades. What appears at first blush as a legislative innovation derives its true value and significance from the fact that it restores the contact with a past that has given the problem a more imaginative and penetrating analysis than has characterized the tentative and stopgap legislation of our days.

As early as 1920 the Supreme Court pointed to the policyholders as the true principals and to the company's services rendered to them as a group of "cooperators":

[T] $\mathrm{T}$ e service performed in level-premium life insurance is both protection and investment. Premiums paid ... . have earned so much for the cooperators, that the company is able to pay to each not only the agreed amount but also additional sums called dividends; and have earned

86. Bell, Federal Taxation of Insurance Companies, 3 Tax Revision Conpendrum 2055, 2056 (1959).

87. Life Insurance Fact Book 1959, at 61-64. 
these additional sums, in part at least, by transactions not among members, but with others; as by lending the money of the cooperators to third persons ....88

Quite similar language was used by Judge Learned Hand in a capital stock tax case which arose under the Revenue Act of 1918 and permitted an informative glance at that of 1916 :

The policy holders are therefore at once associates in the business of life insurance, as to which they are investors, and creditors of the group as a whole.

For it is possible to regard the policy holders even of a stock company as also associates in the enterprise, and perhaps that is the juster view.

The law of 1916 taxed only stock insurance companies, and excluded from capital "such deposits and reserve funds as they are required by law or contract to maintain or hold for the protection of or payment to or apportionment among policy holders." Rev. Act of 1916, \$ 407 (39 Stat. 789). It apparently presupposed that policies were not liabilities, though it did not say so.

The profits do not even come altogether from premiums; in part at any rate they result from the financial operations of the whole group, which thus makes profits or losses as such. ${ }^{80}$

With all due respect for the great judge's artistic penchants, this is not a poet's allegoric fantasy, but a thoroughly prosaic appraisal of the life insurance business in the light of a law which was not half as explicit and forceful in stressing the role of the policyholders as a group as the Act of 1959.

Subsequent legislation introduced the reserve "deduction" in recognition of the amounts set aside for reserve. The term "deduction," addressing itself primarily to the arithmetical result, is of little assistance when the problem is the intrinsic nature of the allowance. It covers such exclusionary items as a life insurance company's exemption of municipal or state bond interest and typical "passing-through" of income in kind, as in the case of a trust's distributions deductions. In the former sense, the term might support the companies' theory of allowing for an expense-like ${ }^{90}$ outgo inevitably connected with their business but not affecting their beneficial interest in all their investment earnings. In the latter sense the term would connote a routing of earnings to those for whom they have been produced and collected. It is interesting to note that where courts have felt the need for closer analysis-it is one of the weaknesses of National Life that it did not recognize such a need despite the government's argument: "No complaint may fairly be made because the statute does not permit petitioner to deduct the sane income twice"91 — they have identified the reserve deduction as a deduction not for an item of expense or "interest," but for income which they have collected only to pass on again. For example,

88. Penn Mut. Co. v. Lederer, 252 U.S. 523, 534 (1920). (Emphasis added.)

89. New York Life Ins. Co. v. Bowers, 39 F.2d 556 (2d Cir. 1930), aff'd, 283 U.S. 242 (1931). (Emphasis added.)

90. See McClatchey, supra note 33 ("expense requirement").

91. National Life Ins. Co. v. United States, 277 U.S. 508, 515 (1928). 
Judge Disney of the Tax Court concludes: "It thus appears that the 33/4 per cent deduction based upon the mean of reserves is an attempt to render tax-free an amount sufficient to cover the amount of income which must actually go into policy reserves under the state statutes governing insurance companies."92

Outside the tax field, and free from the terminological impediment of a particular statute, the authorities are even more emphatic in centering their attention on the direct relationship between the reserve and the policyholders as a group. "Individual policyholders living in many different states who own policies in a single company have their separate interests blended in one assembled fund of assets upon which all are equally dependent for payment of their policies."93

Leading texts in the insurance field speak of the life insurance reserve as "funds which are in their nature trust funds," belong to the company but is held in trust for the policyholder at an assumed rate of interest." 95

None of these utterances, it should be noted, purports to deal specifically with the treatment of tax-exempt interest. Each has its own reason to search for the key to the puzzling problem of properly classifying one of the most remarkable inventions of the human mind. And considering how much the industry owes to the creative thinking of the insurance expert, mathematicians, and even astronomers, and how little to the lawyer, who has always remained on the defensive in this field, it is particularly striking that it is the student of insurance who applies the strongest term for a fiduciary relationship, the word "trust."

A consensus of this weight and variety of perspectives is not readily discarded as a theorist's pipedream. When, in addition, it is sanctioned with the official seal of the United States, it is not overcome by a mere "see however" reference to any school of thought which may align the policyholder with an ordinary bank depositor. In the presence of adequate rational and historic support for such a theory there is the necessary support for denying the company the benefit of the interest exemption which is inseparably attached to the burden of accountability for income. ${ }^{96}$ Moreover, there can be no

92. Reserve Loan Life Ins. Co., 4 T.C. 732, 738 (1945). (Emphasis added.) See also Massachusetts Mut. Life Ins. Co. v. United States, 74 Ct. Cl. 162, 56 F.2d 897 (1932). See generally MERTENS $\$ 36.11$ (1934 ed.); id. § 44.28 (1942 \& 1957 ed.).

The verbal variations are numerous. Thus, Commissioner v. New York Life Ins. Co., $65 \mathrm{~F} .2 \mathrm{~d} 347,349$ (2d Cir. 1933), considers the sum deductible as additions to reserve as "not received as taxable income."

93. United States v. South-Eastern Underwriters Ass'n, 322 U.S. 533, 541 (1944). (Emphasis added.) While referring to fire insurance, the passage applies a fortiori to life insurance.

94. Maclean 265. (Emphasis added.)

95. HUEBNER \& Black 6. (Emphasis added.)

96. The same logic is applied to the trustee of an ordinary trust. $\mathrm{He}$ is not discharged of taxwise responsibility merely by reason of his setting aside and accumulating income for the beneficiary. In this respect less is being required of a life insurance company. But 
quarrel with the "each and every item" method of apportionment, since, if a partition is to be made at all, there could be no method more equitable and less discriminatory than "across the board" approach, the same as the Code, by the so-called character rule, provides for the comparable problem of a trust or estate. ${ }^{97}$

The fact that policyholders do not pay current taxes upon "their" share of the investment earnings, and thereby make no use of the attached interest exemption, should not obscure the issue. Sooner or later, when the present shelter for tax-free reserve accumulation is being removed, the need for joining the good with the bad will become more evident. For the time being, however, exemption wasted should not be confused with exemption denied.

\section{Coda}

The controversy over the tax-exempt interest collected by life insurance companies is but a revised edition of the old problem of "duplication of benefits" which has plagued Congress since the Revenue Act of 1921. It has now become a battle of the fictions. Since in the legal field a fiction rises in value with its proximity to, not with its distance from, realities, and since Congress enjoys a privileged position in the creation and application of legal fictions, the revival of the ancient tax-exempt interest controversy with the benefit of modernized and more efficient legal weapons may well have an outcome vastly different from the National Life verdict of 1928.

Such an outcome could have more profound repercussions than were anticipated by the companies which voiced their objections to the reduction of their reserve deduction under the House bill. Once there is a "policyholders' share" on the books, and its validity is judicially recognized, there is a tempting object for a new tax. If it is not yet being exploited, the credit will not be due to the companies which so inflexibly insisted on their ounce of flesh. Perhaps right should not yield to might. Yet at times it does well to yield to plain good business.

once he is "discharged" by reason of required or authorized actual distribution, the benefit of the interest exemption is pro-rata lost to him and moves to the beneficiary. The beneficiary may or may not have sufficient income to derive an actual benefit from the exemption of interest. It is definitely not a part of the federal commitment to the states with regard to their borrowing power to keep the federal taxes high enough to make the interest exemption attractive.

97. INT. REv. CODE OF 1954, §§ 652(b), 662(b). 